\title{
Investigation on Electrochemical Jet Machining of High Volume Fraction $\mathrm{SiC}_{\mathrm{p}} / \mathrm{Al}$ Composite
}

\author{
Zhuang Liu', Changshui Gao!, , Yi Qiu, Chao Guo \\ College of Mechanical and Electrical Engineering, Nanjing University of Aeronautics and \\ Astronautics, 29 Yudao Street, Nanjing 210016, China \\ 'These authors contributed equally to this work and should be considered co-first authors \\ *E-mail: meecsgao@ nuaa.edu.cn
}

doi: $10.20964 / 2020.04 .27$

Received: 13 November 2019 / Accepted: 16 January 2020 / Published: 10 March 2020

$\mathrm{SiC}$ particles reinforced aluminum matrix composites $\left(\mathrm{SiC}_{\mathrm{p}} / \mathrm{Al}\right)$ is a class of materials with a wide potential for application in aerospace and electronic packaging. High volume fraction reinforcement $\mathrm{SiC}_{\mathrm{p}} / \mathrm{Al}$ is very difficult to machine by conventional methods. This research investigated electrochemical jet machining (ECJM) of $65 \%-\mathrm{SiC}_{\mathrm{p}} / \mathrm{Al}$ composite with absence of and presence of abrasive assistance. The machining capability and material removal mechanism have been analyzed for the jet process. The results show that the material removal mechanism involves corrosion of matrix followed by SiC particles pullout. The presence of abrasives in the ECJM process can remove oxide layer generated at aluminum surface and results in relatively higher machining rate than pure ECJM. The craters due to SiC particles pullout and $\mathrm{SiC}$ protrusion due to corrosion of matrix significantly affect roughness of the machined surface.

Keywords: electrochemical jet machining; abrasive assisted electrochemical jet machining; SiC particles reinforced aluminum matrix composite, material removal mechanism.

\section{FULL TEXT}

(C) 2020 The Authors. Published by ESG (www.electrochemsci.org). This article is an open access article distributed under the terms and conditions of the Creative Commons Attribution license (http://creativecommons.org/licenses/by/4.0/). 